\title{
Citation:
}

Article No.: 2388

Пилипенко, Г. (2021). Некоторые контактнообусловленные явления в словенском диалекте долины Натизоне. Slavia Meridionalis, 21, Article 2388. https://doi.org/10.11649/sm.2388 Pilipenko, G. (2021). Nekotorye kontaktnoobuslovlennye iavleniia v slovenskom dialekte doliny Natizone. Slavia Meridionalis, 21, Article 2388. https://doi.org/10.11649/sm.2388

\section{Глеб Пилипенко}

Институт славяноведения

Российской академии наук

https://orcid.org/0000-0002-5422-0039

\section{Некоторые контактнообусловленные явления в словенском диалекте долины Натизоне}

0. На диалекте долины реки Натизоне (ит. Natisone, словен. Nadiža, словен. диал. Nediža) говорят на западе словенского языкового ареала в провинции Удине в Италии. Относится он к приморской группе словенских говоров, на протяжении своего развития находился в контакте с романским языковым ареалом: с фриульским и итальянским (венецианские диалекты) языками. В отличие от словенского сообщества в соседних провинциях Гориция и Триест у словенцев в Удине национальное движение не имело такого размаха, не было и образования на словенском языке (единственным исключением можно назвать двуязычную школу в Сан-Пьетро-аль-Натизоне, см. подробнее Mezgec, 2017). Из-за установившейся в 1866 году границы между Италией и Австрией кон-

This work was supported by Russian Science Foundation, grant no. 20-78-10030 "The language and cultural contact during the social transformations among the national minorities in Alpine-Pannonian region".

Competing interests: no competing interests have been declared.

Publisher: Institute of Slavic Studies, Polish Academy of Sciences.

This is an Open Access article distributed under the terms of the Creative Commons Attribution 3.0 PL License (creativecommons.org/licenses/by/3.0/pl/), which permits redistribution, commercial and non-commercial, provided that the article is properly cited. ๑ The Author(s) 2021. 
такты с остальными словенскими землями были ограничены. Напротив, взаимодействие с романскими соседями и влияние фриульского языка, позже итальянского, в этом регионе было интенсивным (об истории и языковой ситуации см. Dapit, 2007).

Говорам в долине Натизоне «повезло», их состояние зафиксировал еще в XIX веке И. А. Бодуэн-де-Куртенэ (Baudouin de Courtenay, 1988). Затем они находились в центре внимания лингвистов, фольклористов (Hočevar, 1990; Ivančič Kutin, 2016; Logar, 1983; Šekli, 2007; Skubic, 1997a; Špehonja, 2012; Zuljan Kumar, 2003, 2014 и др.). Много работ посвящено вопросам романского влияния на этот диалект, в частности рассматриваются семантические кальки, синтаксические конструкции, заимствованная лексика (см. работы: Skubic, 1986, 1991), описывается социолингвистическая ситуация. Поскольку обсуждаемый диалект находится на крайнем западе словенской этнической территории и граничит непосредственно с фриульскими диалектами, он является интересным примером славяно-романских языковых контактов, активных и по сей день. Наше внимание и привлекло именно это обстоятельство, как и то, что материалы И. А. Бодуэна-де-Куртенэ могут послужить отправной точкой для временной фиксации языковых изменений. В 2017 и 2018 годах были проведены экспедиции в следующих населенных пунктах: Сан-Пьетро-аль-Натизоне (ит. San Pietro al Natisone, словен. Špeter), Вернассо (ит. Vernasso, словен. Vernas), Кросту (ит. Crostù, словен. Hrastovije), Монтемаджоре (ит. Montemaggiore, словен. Matajur), Массерис (ит. Masseris, словен. Мašera), Ознебрида (ит. Oznebrida, словен. Očna brda) (Удине, Фриули-Венеция-Джулия) ${ }^{1}$. Во время экспедиции, полуструктурированных интервью, ученых интересовала социолингвистическая ситуация, а также этнолингвистические сведения в области календарной, семейной обрядности и в мифологии. В настоящей статье рассматриваются лишь отдельные самые характерные и часто встречаемые в корпусе явления в фонетике, морфологии и синтаксисе, некоторые из них не обсуждались до сих пор в специальной литературе. В ходе анализа материала предстоит ответить на вопросы: какова роль романских языков в формировании этих явлений, установить особенности их функционирования, а также понять их место на ареальной лингвистической карте юго-восточной Европы.

1 Было опрошено 25 информантов среднего и пожилого возраста. 
Глеб Пилипенко Некоторые контактнообусловленные явления в словенском диалекте...

1. Из фонетических явлений обращает на себя внимание озвончение глухого свистящего $s$ в позиции перед сонорными $m, l$ :

\begin{tabular}{|c|c|}
\hline $\begin{array}{l}\text { 1.1. Zak kri se nije zmielo z } \gamma \text { ubit nic kervé, se } \\
\text { j wso kri ujelo<? }>\end{array}$ & $\begin{array}{l}\text { Потому что кровь нельзя было } \\
\text { упустить, всю кровь собирали }(\mathrm{L} \check{S})<?>\end{array}$ \\
\hline 1.2. Ma tu no uro se na rivá zmizlit usé & $\begin{array}{l}\text { Но тут за один час не получается } \\
\text { вспомнить все (LŠ) }\end{array}$ \\
\hline $\begin{array}{l}\text { 1.3. Učitelce niso zmele, smele yovorit po tali- } \\
\text { jansko, je blo prepovedano }\end{array}$ & $\begin{array}{l}\text { Учительницы не смели говорить } \\
\text { по-итальянски<?>, было запрещено } \\
\text { (LB) }\end{array}$ \\
\hline
\end{tabular}

Происходит это явление не только в начале слова, но и, как видно в 1.2, в середине. В грамматике надижского диалекта упомянуто лишь, что «z не произносится перед c, č, f, h, k, p, t, s, š, t» (Špehonja, 2012, с. 27). В итальянском языке глухой свистящий озвончается перед сонорными в начале слова (Челышева \& Черданцева, 2001, с. 66). Таким образом, очевидно, что речь идет о фонетической интерференции. Озвончение $s$ в этой позиции воспринимается говорящими как несвойственное фонетической системе их диалекта, что подтверждает автокоррекция в 1.3. О том, какую роль может играть это явление в условиях итальянско-словенских языковых контактов, свидетельствует пример, записанный в Гориции. Итальянцы произносят словенское имя Jasna с озвончением, что созвучно со словенским словом јеzпа (злая) (ПМА, 2017-2018), для словенцев очевидна негативная ассоциация при подобном произнесении.

Данная фонетическая особенность реализуется не всегда, это ситуативный феномен, происходящий под воздействием итальянского языка. В корпусе текстов все же доминируют случаи, когда озвончение перед сонорными не происходит. Однако в языке информантов, языковая компетенция которых на словенском диалекте редуцированная, а итальянский язык в их языковом репертуаре преобладает, таких случаев ожидаемо фиксируется больше. Необходима более длительная временная дистанция для того, чтобы понять, получит ли эта фонетическая черта дальнейшие распространение.

2. Были зафиксированы заимствованные из итальянского языка предлоги:

2.1. Zak se niso poznal fra-a oni-i, zak se veckrat preubliekli

Потому что они не были знакомы друг с другом, потому что они много раз переодевались (SB) 
Глеб Пилипенко Некоторые контактнообусловленные явления в словенском диалекте...

\begin{tabular}{|c|l|}
\hline $\begin{array}{l}\text { 2.2. Nas je bluo w šuoli sedendesét } \\
\text { otruok, fra-a-a, kar ih je blo pet }\end{array}$ & $\begin{array}{l}\text { Нас было в школе семьдесят детей } \\
\text { среди-и, что их было пять (SB) }\end{array}$ \\
\hline $\begin{array}{l}\text { 2.3. Ma tisto je pomayalo, fra judjé se j } \\
\text { pomayalo }\end{array}$ & $\begin{array}{l}\text { Ну в этом помогали, между людьми } \\
\text { помогали (SB) }\end{array}$ \\
\hline $\begin{array}{l}\text { 2.4. Puno otrouk nas je bluo, smo hodil } \\
\text { vsi, fin do kuarte, an tadá kwinta-a }\end{array}$ & $\begin{array}{l}\text { Много нас было детей, мы все ходили, до } \\
\text { четвертого класса, а потом пятый класс (MT) }\end{array}$ \\
\hline $\begin{array}{l}\text { 2.5. Zok su jal, de je od božíča more pridit } \\
\text { fin do-o svetih trieh krajúw }\end{array}$ & $\begin{array}{l}\text { Потому что говорили, что от Рождества } \\
\text { может прийти до Трех королей (VC) }\end{array}$ \\
\hline
\end{tabular}

В корпусе собранных текстов наиболее часто встречаемые заимствованные предлоги - fra, fin do. Первый - однокомпонентный, второй двухкомпонентный. Предлог fra фиксируется только в такой форме, тогда как в итальянском языке существует его разновидность с инициальным $t$ : tra. Предлог tralfra есть и во фриульском (Нарумов \& Сухачев, 2001, с. 380). В словенских диалектах долины Натизоне он функционирует наряду с предлогом med (Špehonja, 2010, c. 103), что подтверждают данные и нашего корпуса; таким образом, речь идет о вариативности.

Составной предлог fin do имеет два компонента: итальянский и словенский, в этом смысле его можно назвать контаминированным. По всей видимости, составные предлоги с итальянским и словенским элементом - известное явление в диалектах итальянско-словенского пограничья ${ }^{2}$ : например, в резьянских говорах находим составной предлог dopo po (Steenwijk, 1992, c. 165). Анализируемый предлог является калькой итальянского аналога fino $a$ (вплоть, до). Fin возник в результате усечения итальянской основы, а словенский предлог do соответствует предлогу $a$ (и его вариантам с артиклем al, allo, all', alla, ai, agli, alle). В словаре терского диалекта Бодуэн-де-Куртенэ зафиксировал составной предлог с тем же значением fin+će, также состоящий из романского и словенского компонентов (Spinozzi Monai, 2009, c. 385). В грамматике диалекта долины Натизоне отмечается только предлог do (Špehonja, 2012, c. 156) как аналог итальянского fino a. Однако, судя по нашим материалам, fin do функционирует наряду с $d o$.

Предлог fra во всех встречаемых позициях сочетается с именительным падежом имен: cp. fra oni, fra judje, в чем также можно усмотреть влияние итальянского языка, в котором изменение имен по падежам отсутствует. Такая ситуация в принципе нетипична для славянских языков, в которых

2 Как, собственно, и заимствование предлогов, например, в резьянском: $d s p o$, kuntra (ср. ит. dopo, contra) (Steenwiik, 1992, с. 162). 
предлоги, как правило, не сочетаются с именами в именительном падеже 3 . Аналогичный словенский предлог med требует после себя в зависимости от значения либо винительного падежа (при направлении движения), либо локатива (при обозначении местонахождения). В говоре резьянских словенцев также присутствует предлог fra, при этом fra - единственный предлог, который сочетается с номинативом: ni so se znali fra una, fra judi (Steenwijk, 1992, c. 162) (примеры с теми же существительными, что и в нашем корпусе).

После fin do используется родительный падеж, в приводимых примерах находим формы род. п. сущ. ж. p. (fin do kuarte) и сущ. м. р. в мн. ч. (fin do-o svetih trieh krajuw). Появление родительного падежа обусловлено вторым словенским компонентом $(d o)$, который, будучи употреблен самостоятельно, требует родительного падежа.

\section{3. Среди контактных элементов находим союзы.}

3.1. Te liepe so ble liepuo ubliečene, so bli, o je biw kraj, krajíca, o je biw, novíc

3.2. Ma moja mama ya j klicala Janez, ja, o-o Giuseppe, Jožef, so bli wse priimki

3.3. Če so miel kake, o-o, slačino, o karamelo

3.4. Su bli lešinki, orieh, an su dal mayar nu mikanu mandarin, o narancu, za Svetu Luciju tuole

3.5. Na vilju božiča, o na vilju zadnjeja lieta

3.6. An takú je ostalo, Miha Mihacof, opur Furianof, op- Florán je bil Flóran, opur-r-r e-e Martinkini
Эти красивые были красиво одеты, были, или был король, королева, или был жених (L $\check{S})$

Моя мама его звала Янез, да, или Джузеппе, Йожеф, были все фамилии (SiB)

Если были у них какие, или сладости, или конфета ( $\mathrm{SiB})$

Были лесные орехи, орех, и давали небольшой мандарин, или апельсин, на святую Луцию это было (VC)

В сочельник или в сочельник последнего года (VC)

И так осталось, Миха Михацов, или Фурианов, или Флоран был, Флоран, или э-э Мартинкини (SiB)

Рассмотрим два союза, которые заимствованы из итальянского языка ${ }^{4}$ и чаще всего фиксируются в нашем корпусе: о и оррure (o, oppure - или). Оба союза используются при перечислении со значением 'или' и могут образовывать несколько рядов перечисления (или... или... или). Союз о отмечен в словаре (Špehonja, 2010, p. 134), тогда как ориг не обнаружен.

${ }^{3}$ Например, в резьянском после союзов dspo u kuntra используются дательный/ местный падежи (Steenwiik, 1992, с. 162).

4 Во фриульском также функционируют союзы $о$ (Нарумов \& Сухачев, 2001, p. 380) и opur (Frat, 2008, p. 539). 
Глеб Пилипенко Некоторые контактнообусловленные явления в словенском диалекте...

Однако в терском диалекте opur фиксируется уже Бодуэном-де-Куртенэ (Spinozzi Monai, 2009, p. 189).

Как и в случае с предлогами, мы наблюдаем вариативность: в словенском диалекте долины Натизоне параллельно используются исконные союзы с тем же значением, например, для союза al (pa) указаны итальянские соответствия: $о$ и орpure (Spinozzi Monai, 2009, p. 9). Союз о очень легко проникает в систему славянских языков при славяно-романских языковых контактах (ср. его появление в переселенческих хорватских говорах в Чили (исп. o - или) (može se stavit jedan komad o jedna grana (можно положить одну штуку или одну ветку) (ПМА, 2017)5). В нашем корпусе также наблюдается вариативность указанных союзов, при этом частотность итальянских союзов ниже, чем у словенских аналогов.

4. В области порядка слов обращает на себя внимание часто встречаемая (по сравнению с литературным словенским языком) правая позиция прилагательного по отношению к определяемому существительному.

\begin{tabular}{|c|c|}
\hline $\begin{array}{l}\text { 4.1. An so nam napravel žake biele, se perešil } \\
\text { s telih erjúh starih }\end{array}$ & 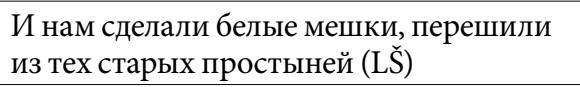 \\
\hline $\begin{array}{l}\text { 4.2. An pod vasjó so hudil, so miel klabučice } \\
\text { erdec }\end{array}$ & $\begin{array}{l}\text { И внизу под селом ходили, у них были } \\
\text { красные шляпы (LS) }\end{array}$ \\
\hline 4.3. Niso kupovali ure zlaté en tiste reči & $\begin{array}{l}\text { Они не покупали золотые часы и эти } \\
\text { вещи (LŠ) }\end{array}$ \\
\hline $\begin{array}{l}\text { 4.4. So se zbral za reči publike, zak niso plac- } \\
\text { jál }\end{array}$ & $\begin{array}{l}\text { Они собирались для общественных } \\
\text { дел, потому что они не платили (LS) }\end{array}$ \\
\hline $\begin{array}{l}\text { 4.5. Nastavijo yor eno smrieko, no smrieko } \\
\text { yor, e, bandiero talijansko, ja, bandiera } \\
\text { talijanska }\end{array}$ & $\begin{array}{l}\text { Поставят сосну, сосну, наверх, э, } \\
\text { итальянский флаг, да, итальянский } \\
\text { флаг (DC) }\end{array}$ \\
\hline 4.6. Allora, tisti, ki niso miel otruok majhanih & Итак, те, у кого были маленькие дети (МТ) \\
\hline
\end{tabular}

В итальянском языке качественное прилагательное следует за существительным в ограничительной или дистинктивной функции, в постпозиции стоят также относительные и многосложные прилагательные (Челышева \& Черданцева, 2001, р. 85). На романское влияние в постановке прилагательных после существительного в западных словенских наречиях, в частности, в диалекте долины Натизоне, ука-

5 При этом предлоги в переселенческие славянские говоры Южной Америки заимствуются очень редко, в основном - в случае редуцированной языковой компетенции на L1: укр. xodyly xata por xata (исп. casa por casa) (ПМА, 2017). 
зывают (Smole, 2001; Skubic, 1991, p. 362). Д. Зулян Кумар отмечает, что в бришских и надижских говорах правое или левое расположение прилагательного стилистически нейтрально и может варьироваться в речи (Zuljan Kumar, 2003, p. 63). Однако в грамматике надижского диалекта о месте прилагательного ничего не говорится (Špehonja, 2012). В соседних со словенскими говорами фриульских диалектах (окрестности Кормонса) левое или правое расположение также нейтрально (Zuljan Kumar, 2003, p. 65).

Анализируемое явление фиксируется еще в записях Бодуэна-де-Куртенэ из долины Натизоне: štir an dvojst kō $b i e \bar{l} l i h$ (Baudouin de Courtenay, 1988, p. 156) ${ }^{6}, j$ pœršu puob liep (Baudouin de Courtenay, 1988, p. 162), а также из Терской долины, что свидетельствует о его широком распространении как минимум уже сто пятьдесят лет назад: nu majø dostb besjēt laškbx, nu majø jazbk krayoli (Бодуэн-де-Куртенэ, 1904, р. 33). Распространена постпозиция прилагательного в говоре молизских хорватов (Breu, 2019, p. 416). В переселенческих чешских говорах Румынии это явлении также приписывается влиянию языка романского окружения - румынского (см. Frnochová, 2012, с. 79; Utěšený, 1964 c. 31). В переселенческих славянских идиомах, ранее не имевших контактов с романским языковым ареалом и функционирующих в новых условиях не более ста лет, также фиксируются примеры с постпозицией прилагательного по отношению к существительному ${ }^{7}$, т. е. речь идет о явлении, которое проникает в языковую систему за достаточно короткий (с точки зрения языкового развития) временной промежуток.

В записанных нами примерах одно и то же прилагательное может располагаться как в препозиции, так и в постпозиции к существительному без изменения оттенка в значении. Это свидетельствует о вариативном характере данного явления. В примере 4.4 наблюдаем заимствованное прилагательное publike, согласуемое с существительным по роду и числу (ж.р., мн. ч.). Это обстоятельство является дополнительным облегчающим фактором при

${ }^{6}$ При этом в параллельных записях на современном надижском диалекте в этих конструкциях место прилагательного изменено: štirandvajst bielih konju (Baudouin de Courtenay, 1988, p. 156), an liep puob (Baudouin de Courtenay, 1988, p. 162).

7 Испанские прилагательные в постпозиции имеют классифицирующую функцию (Нарумов, 2001, с. 440). Ср., в переселенческих украинских говорах Аргентины в испанском окружении: ws'o tuta zyml'a misjonyska (исп. tierra misionera), xl'ip solotkyj (исп. pan dulce) (ПМА из Аргентины, Чили, 2017). 
Глеб Пилипенко Некоторые контактнообусловленные явления в словенском диалекте...

выборе позиции в предложении: происходит не только перенос внешней оболочки (ср. ит. le cose pubbliche), но и его местоположения в высказывании. Похожий фактор действует и в 4.5, где заимствованным является уже существительное, а прилагательное имеет словенскую форму. В других случаях (например, 4.1, 4.2) существительное и прилагательное словенские по происхождению, тем не менее они следуют данной модели.

5. Характерной чертой словенских говоров долины Натизоне является удвоение местоимений.

\begin{tabular}{|l|l|}
\hline $\begin{array}{l}\text { 5.1. Comunque, tisto je bluo, anta potle mene } \\
\text { m so zapejál kad sem mela, k sam hodi- } \\
\text { la-a, quintoo }\end{array}$ & $\begin{array}{l}\text { В любом случае, это было, и потом } \\
\text { меня отвели, когда мне было, когда } \\
\text { я ходила в пятый класс (MT) }\end{array}$ \\
\hline $\begin{array}{l}\text { 5.2. Anta si moraw ti uteč, an ih so ih bli } \\
\text { zaž jali, al pa ubili, a tele so se skrivále }\end{array}$ & $\begin{array}{l}\text { И затем ты должен был убежать, а их } \\
\text { сожгли, или убили, а те прятались (SB) }\end{array}$ \\
\hline $\begin{array}{l}\text { 5.3. Potem tako mené mi je ostalo v sarcu, } \\
\text { močnuo v sarcu }\end{array}$ & $\begin{array}{l}\text { И потом у меня осталось в сердце, } \\
\text { сильно в сердце (LB) }\end{array}$ \\
\hline $\begin{array}{l}\text { 5.4. Ker sem prow napisala, mene mi vseć } \\
\text { tudi pisát }\end{array}$ & $\begin{array}{l}\text { Потому что я правильно написала, } \\
\text { мне нравится также писать (LB) }\end{array}$ \\
\hline $\begin{array}{l}\text { 5.5. Antadá, me oni me su jal: kdo je tam not? } \\
\text { И потом они мне сказали: кто там } \\
\text { внутри? (VC) }\end{array}$ \\
\hline $\begin{array}{l}\text { 5.6. Mene me je blo liəpo žе kr səm bla məj- } \\
\text { hana }\end{array}$ & $\begin{array}{l}\text { Мне было хорошо, что я была } \\
\text { маленькая (LC) }\end{array}$ \\
\hline
\end{tabular}

Удвоение местоимений - черта, встречающаяся не только в словенских говорах западного ареала (Smole, 2001), но и в славянских балканских языках, в частности, в балкано-романских языках (Лухт \& Нарумов, 2001, pp. 628-629) (о типологии данного явления см. Аркадьев, 2016). Эта особенность отмечается в испанском языке, в диалектах итальянского языка, в том числе и в распространенных в рассматриваемом регионе венецианских диалектах, а также во фриульском языке ${ }^{8}$ В литературном итальянском дублирование местоимением обязательно для прямого объекта и факультативно в других случаях (Челышева \& Черданцева, 2001, p. 86). Во фриульском для устной речи характерна антиципация прямого и косвенного дополнения (Нарумов \& Сухачев, 2001, p. 388).

${ }^{8}$ В качестве типологической параллели отметим, что в северно-итальянских диалектах, а также во фриульском языке функционируют особые субъектные клитики (Челышева, 2001, p. 122; Нарумов \& Сухачев, 2001, pp. 378-379). Однако они никак не копируются словенскими говорами долины Натизоне (Skubic, 1986, p. 65). Субъектные клитики при этом отмечаются в резьянском, где появились под влиянием фриульского (Runić, 2018). 
Глеб Пилипенко Некоторые контактнообусловленные явления в словенском диалекте...

Очевидно, что рассматриваемое явление свойственно словенским западным периферийным говорам, находящимся в контакте с романскими идиомами. Удвоение местоимений фиксирует М. Скубиц в диалекте долины Натизоне: mene me je všeč bit dol v dolini (Skubic, 1997a, p. 102), однако отмечает, что это явление, как и местоименная реприза при существительном (см. раздел 6), «non è nello spirito della lingua slovena (не в духе словенского языка) (Skubic, 1986, p. 65)». В резьянском ударные формы следуют вместе с неударными, если они выделены логически и интонационно (Steenwijk, 1992, p. 119). В говорах терской долины (записи конца

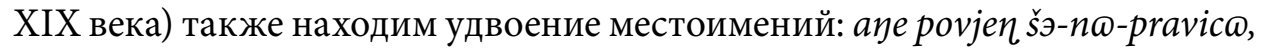
k-mi-sэ-jэ-yodila mэnэ (Бодуэн-де-Куртенэ, 1904, р. 11).

Р. Бенаккьо говорит, что это удвоение чуждо славянским языкам, и оно наблюдается там, где в прошлом был контакт с романским населением, в частности, в хорватских говорах Истрии (ср. mene me boli glava (Benacchio, 2007, p. 39)), отмечается влияние фриульского языка при появлении удвоения в языке словенцев в провинции Фриули (Benacchio, 2007, p. 39). Дублирование при помощи клитик у молизских хорватов следует правилу южноитальянских диалектов, в которых оно происходит в том числе в позиции, если удваиваемый объект находится после глагола (Breu, 2019, pp. 423-425).

В приводимых примерах реализуются две позиции, в которых происходит удвоение местоимения: позиция винительного падежа $(5.1,5.2)$ и позиция дательного падежа $(5.3,5.4,5.5,5.6)$. Как правило, местоимения следуют друг за другом, однако в двух случаях этот порядок нарушается: в 5.2 и 5.5. В этих примерах между первым и вторым местоимениями вклиниваются дополнительные элементы, например, форма вспомогательного глагола (5.2), личное местоимение третьего лица мужского рода множественного числа (5.5). По всей видимости, такой порядок характерен, когда оба местоимения употреблены в краткой форме (!), постановка их в одном ряду выглядела бы странной, а высказывание воспринималось бы неоднозначно. Как и в предыдущих случаях, речь идет о вариативности: в нашем корпусе отмечено как удваивание местоимений, так и формы без дублирования. При этом заметно, что местоимения несут на себе дополнительный акцент и логически выделены. Конкурирование форм с удвоением и без удвоения встречается в сербском языке банатской Черногории на территории Румынии, где эти формы объясняются воздействием румынского языка (Симић, 2013, 
Глеб Пилипенко Некоторые контактнообусловленные явления в словенском диалекте...

pp.431-433). В этом контексте весьма важным представляется наблюдение Р. Бенаккьо, которая проводит параллели между идентичными романскими контактными явлениями, возникшими в языке словенцев и хорватов Италии, и романским влиянием на славянские языки в балканском ареале (Benacchio, 2007, p. 38).

6. В диалекте долины Натизоне происходит удвоение существительных при помощи местоимённых клитик, местоименная реприза:

\begin{tabular}{|c|c|}
\hline $\begin{array}{l}\text { 6.1. A oljko, kar jo nesijo oljko tist je nor- } \\
\text { mál, zak se j dielo tu yolobico tu usta } \\
\text { oljko žejnano }\end{array}$ & $\begin{array}{l}\text { А ветку оливкового дерева, которую несут, } \\
\text { это нормально, потому что голубице (из } \\
\text { теста) в клюв вставляли освященную } \\
\text { ветку оливкового дерева (LŠ) }\end{array}$ \\
\hline $\begin{array}{l}\text { 6.2. Ih nisen miela vec bradovic, an mai vec } \\
\text { potle! }\end{array}$ & $\begin{array}{l}\text { И у меня не было больше бородавок, } \\
\text { и потом никогда больше не было! (SiB) }\end{array}$ \\
\hline $\begin{array}{l}\text { 6.3. Od junija do decembra dnevi, in sonce } \\
\text { tudi, sonce } \gamma \text { a vidiš, ko je bil visok, pod } \\
\text { verhá Matajura se zniža in } \gamma \text { re vedno } \\
\text { dol v dolino }\end{array}$ & $\begin{array}{l}\text { Дни с июня по декабрь, и солнце } \\
\text { также, солнце видишь, когда оно } \\
\text { было высоко, над вершиной Матаюра } \\
\text { (Монтемаджоре) заходит и всегда } \\
\text { заходит вниз в долину (LB) }\end{array}$ \\
\hline $\begin{array}{l}\text { 6.4. Ja, je peršuw dol, mu su dal enjemú, mu } \\
\text { su dal enjemú, an kos, ka ne, de snijá }\end{array}$ & $\begin{array}{l}\text { Да, он спустился, и одному дали один } \\
\text { кусок, чтобы он съел (VC) }\end{array}$ \\
\hline
\end{tabular}

Как и в случае с удвоением местоимений, в приводимых примерах из корпуса наблюдаются две синтаксические позиции: позиция прямого объекта в винительном падеже $(6.1,6.2,6.3)$ и позиция дательного падежа (6.3). При существительном в этих позициях появляется краткая форма личного местоимения, которая с ним согласуется. Существительное может располагаться после удваиваемого местоимения (6.1, 6.2, 6.4), в примере 6.3 находим существительное в препозиции к краткой форме местоимения.

В романских языках местоименная реприза при существительном довольно распространенное явление, наблюдается она в итальянском литературном языке и в венецианских диалектах. Во фриульском также распространена местоименная реприза прямого и косвенного дополнения (Нарумов \& Сухачев, 2001, р. 388), что позволяет отличать тему от контраста.

О романском влиянии при использовании этих конструкций в надижском диалекте пишут М. Скубиц: Roberta ga poznajo puno judi (Skubic, 1997a, p. 102; Skubic, 1986, p. 65), и Д. Зулян Кумар (Zuljan Kumar, 2003, pp. 76-77). Местоименная реприза при существительном отмечается в резьянских говорах (Šekli, 2010; Steenwijk, 1992, р. 119), что является результатом 
контакта с фриульским языком (Šekli, 2010, pp. 137-138). В текстах из долины Натизоне, зафиксированных в XIX веке Бодуэном-де-Куртенэ, эта конструкция также представлена: œentá su jāl, duó ya j sqiédu mēt? (и тогда сказали: кто съел мёд?) (записано в Вернассо (Bernas)) (Baudouin de Courtenay, 1988, p. 22). Однако очевидно, что она не носит обязательный характер 9 . В конкретном же случае речь идет о вопросе с логическим выделением слова в позиции прямого дополнения. Похожую стратегию наблюдаем и в записанных нами примерах, анализируемые фразы произносились с выделительной интонацией.

В ареальном отношении удвоение местоимения и местоименная реприза существительного в западных славянских диалектах на территории Италии образуют разорванный ареал со славянскими языками, входящими в балканский языковой союз.

7. В завершение статьи рассмотрим еще одно явление, которое мы склонны приписывать влиянию романских языков. Ниже представлены конструкции с числительным для обозначения даты:

\begin{tabular}{|l|l|}
\hline 7.1. Na sviečinco, na dva febrarja & На Сретение, второго февраля (LS) \\
\hline $\begin{array}{l}\text { 7.2. Potem sem sla v collegio, na sedem } \\
\text { decembra }\end{array}$ & $\begin{array}{l}\text { Потом я пошла в колледж, седьмого } \\
\text { декабря (LB) }\end{array}$ \\
\hline $\begin{array}{l}\text { 7.3. Jes sen se rodíw, na-na, devetandvest } \\
\text { zenarja }\end{array}$ & $\begin{array}{l}\text { Я родился двадцать девятого января } \\
\text { (VC) }\end{array}$ \\
\hline
\end{tabular}

Особенность этих конструкций состоит в том, что употребляется количественное числительное, а не порядковое, как ожидалось бы в этом случае (ср. словен. sedmega decembra). В ее состав входит предлог па, далее следует количественное числительное, за ним - название месяца в родительном падеже. Обнаруженные контексты, к сожалению, не дают оснований, чтобы понять, в каком падеже стоит числительное после предлога $n a-$ в именительном либо же винительном. Весьма необычным кажется выбор родительного падежа после числительного, стоящего в начальной форме. Логичным выглядело бы использование формы родительного падежа после порядкового числительного. По всей видимости, появлению количественного числительного могла способствовать интерфе-

9 Следует отметить, что в параллельном тексте на современном диалекте долины Натизоне Л. Спиноцци-Монаи не отражает полностью эту конструкцию: Antada su jal: «Duoj sniedu med?» (Baudouin de Courtenay, 1988, p. 22). 
ренция с итальянским языком, в котором во временных конструкциях подобного рода, начиная с числительного due (два), используется как раз количественное числительное (ср. ит. il due febbraio, il sete dicembre, il ventinove gennaio). Полностью калькированной конструкцию признать нельзя, поскольку используется падежная форма названия месяца, а числительному предшествует предлог na, тогда как в итальянском языке употребляется определенный артикль. Данная конструкция довольно часто встречается в корпусе. Появление количественных числительных можно рассматривать как тенденцию к упрощению словоизменения числительных в ситуации славяно-романского контакта.

Кроме того, в текстах, записанных нами, информанты для выражения даты часто используют стратегию переключения кода и переходят на итальянский язык. Эта стратегия широко распространена в том числе и в Резии ${ }^{10}$ (ki je na l'otto settembre (Steenwijk, 1992, p. 218). В резьянских говорах временное значение у предлога па не зафиксировано (Steenwijk, 1992, p. 163), тогда как в говорах словенцев долины Тера Бодуэн-де-Куртенэ в 1901 году записал следующие примеры: na vinti ženārja dal setante nūf; do osin maja (Бодуэн-де-Куртенэ, 1904, p. 7); na trīnajst jū (Бодуэн-де-Куртенэ, 1904, р. 15). Очевидно, что не только с предлогом na, но и с предлогом do употребляются начальные формы количественных числительных. Кроме того, в терском заимствуются как числительные, так и происходит переключение на фриульский при выражении даты (dal setante $n \bar{u} f)^{11}$. В грамматике надижского диалекта отмечается, что дата обозначается при помощи количественного числительного, как в итальянском языке, однако ничего не сказано про падежную форму числительных (Špehonja, 2012, p. 71): donas smo na tri ženarja.

8. Долина реки Натизоне в провинции Удине сегодня является местом интенсивных славянско-романских языковых контактов, что находит отражение в фонетике, морфологии и синтаксисе. Несмотря на то, что о контактах в этом регионе было написано немало, некоторые аспекты остались без должного освещения: озвончение $s$ перед сонорными, использование итальянских предлогов и союзов, временные конструкции для выражения даты. Интерес представляют ареальная

10 А также в славянских переселенческих говорах Южной Америки (ПМА, 2017).

11 Ср. также наш пример из долины Натизоне: na quaranta giorni (на сороковой день) (SB). 
перспектива рассмотренных явлений и временная характеристика. Некоторые конструкции (например, удвоение местоимений, местоименная реприза) демонстрируют сближение с балканской зоной языковых контактов (по всей видимости, можно предположить, что речь идет о разорванном ареале) и средиземноморским регионом, в надижском диалекте они фиксируются с конца XIX века. Рассмотренные явления имеют параллели в романских языках региона, которые способствовали их появлению и закреплению в словенском диалекте долины Натизоне. При этом обсуждаемые конструкции и элементы вариативны и могут конкурировать со своими словенскими аналогами. Одни явления ситуативные и маргинальные (озвончение свистящего перед сонорными), другие являются частью языковой системы (временные конструкции, заимствованные предлоги). Отдельные контактные элементы обладают повышенной «инвазивностью»: постпозиция прилагательного и заимствование союзов характерны также для переселенческих славянских говоров, находящихся в контакте с испанским языком менее ста лет. Установлены и контаминированные формы (предлог fin do, временная конструкция). Дальнейшая обработка записанных материалов и пополнение устного корпуса позволит выявить частотность контактнообусловленных форм и явлений в словенском диалекте долины Натизоне.

\section{БИБЛИОГРАФИЯ}

Аркадьев, П. М. (2016). Роли, иерархии и двойное маркирование объектов. Bопросы языкознания, 2016(5), 7-48.

Бодуэн-де-Куртенэ, И. А. (1904). Матеріалы для южнославянской діалектологіи и этнографіи: Pt. 2. Образцы языка на говорах Терских славян спверовосточной Италіи. Типографія императорской академіи наукъ.

Лухт, Л. И., \& Нарумов, Б. П. (2001). Румынский язык. In И. И. Челышева, Б. П. Нарумов, \& О. И. Романова (Eds.), Языки мира: Романские языки (рp. 574-636). Academia.

Нарумов, Б. П. (2001). Испанский язык. In И. И. Челышева, Б. П. Нарумов, \& О. И. Романова (Eds.), Языки мира: Романские языки (рp. 411-462). Academia.

Нарумов, Б. П., \& Сухачев, Н. Л. (2001). Фриульский язык. In И. И. Челышева, Б. П. Нарумов, \& О. И. Романова (Eds.), Языки мира: Романские языки (pp. 365-391). Academia.

Симић, 3. (2013). Прилог проучавању међујезичке интерференције (на примеру говора Банатске Црне Горе). Јужнословенски филолог, 2013(69), 429-441. https://doi.org/10.2298/JFI1369429S 
Челышева, И. И. (2001). Диалекты Италии. In И. И. Челышева, Б. П. Нарумов, \& О. И. Романова (Eds.), Языки мира: Романские языки (pp. 90-146). Academia.

Челышева, И. И., \& Черданцева, Т. 3. (2001). Итальянский язык. In И. И. Челышева, Б. П. Нарумов, \& О. И. Романова (Eds.), Языки мира: Романские языки (pp. 56-90). Academia.

Baudouin de Courtenay, J. (1988). Materiali per la dialettologia e l'etnografia slava meridionale: Vol. 4. Testi popolari in prosa e in versi raccolti in Val Natisone nel 1873 / Materiali za južnoslovansko dialektologijo in etnografijo: Vol. 4. Ljudska besedila v prozi in verzih, zbrana v Nadiških dolinah leta 1873 (L. Spinozzi Monai, Ed.). Editoriale stampa triestina; Centro studi Nediža.

Benacchio, R. (2007). Slovansko-romanski jezikovni stik v moližanski hrvaščini: Vzporednost s slovenskimi narečji v Furlaniji. Jezikoslovni zapiski, 13(1-2), 33-41. https://doi.org/10.3986 /jz.v13i1-2.2474

Breu, W. (2019). Morphosyntactic changes in Slavic micro-languages: The case of Molise Slavic in total language contact. In A. Danylenko \& M. Nomachi (Eds.), Slavic on the language map of Europe: Historical and areal-typological dimensions (pp. 385-432). De Gruyter Mouton. https://doi.org/10.1515/9783110639223-013

Dapit, R. (2007). Položaj sodobnega slovenskega jezika na Videmskem. In. M. Košuta (Ed.), Živeti mejo (pp. 170-180). Slavistično društvo Slovenije.

Erat, J. (2008). Furlansko-slovenski slovar: I Dizionari furlan-sloven. http://sabotin.p-ng.si / jezik/furlanscina/

Frnochová, A. (2012). Jazyk české menšiny v obci Šumice v rumunském Banátě [Unpublished Master's thesis]. Univerzita Karlova.

Hočevar, M. (1990). Nadiško narečje (glasovje in besedje) v humorističnih sestavkih doma. Slavistična revija, 1990(3), 285-294.

Ivančič Kutin, B. (2016). Bivališča krivopet: Lokacije in mikrotoponimi. Studia Mythologica Slavica, 19, 169-185. https://doi.org/10.3986/sms.v19i0.6620

Logar, T. (1983). Slovenska narečja. Mladinska knjiga.

Mezgec, M. (2017). Slovenščina v beneški Sloveniji in vloga dvojezične šole v Špetru pri medgeneracijskem prenosu jezika: stališča staršev. Slovenščina 2.0, 5(2), 1-32. https://doi.org /10.4312/slo2.0.2017.2.1-32

Runić, M. (2018). Slovensko-romanski jezički kontakt na primeru dve pojave iz rezijskog. Slavia Meridionalis, 18, Article 1657. https://doi.org/10.11649/sm.1657

Šekli, M. (2007). Fonološki opis govora vasi Jevšček pri Livku nadiškega narečja slovenščine. Jezikoslovni zapiski, 13(1-2), 409-427. https://doi.org/10.3986/jz.v13i1-2.2508

Šekli, M. (2010). Zaimkovno podvajanje predmeta in osebka v rezijanskem narečju slovenščine: (S stališča jezikovnega stika s furlanščino). In Makedonsko-slovenečki jazični, kniževni i kulturni vrski / Makedonsko-slovenske jezikoslovne, književne in kulturne zveze (pp. 133-155). Filološki fakultet «Blaže Koneski», Univerzitet «Sv. Kiril i Metodij».

Skubic, M. (1986). Interferenze linguistiche slavo-romanze: La lingua di Novi Matajur. Linguistica, 26(1), 59-68. https://doi.org/10.4312/linguistica.26.1.59-68 
Глеб Пилипенко Некоторые контактнообусловленные явления в словенском диалекте...

Skubic, M. (1991). Interferenze sintattiche di origine romanza nelle parlate slovene occidentali: la strutturazione del sintagma aggettivale, della frase, del periodo. Linguistica, 31(1), 361-365. https://doi.org/10.4312/linguistica.31.1.361-365

Skubic, M. (1997a). Calchi di provenenza romanza nello sloveno occidentale. Linguistica, 37(1), 99-105.

Skubic, M. (1997b). Romanske jezikovne prvine na zahodi slovenski jezikovni meji. Znanstveni inštitut filozofske fakultete.

Smole, V. (2001). Zahodna slovenska narečja. In M. Javornik (Ed.), Enciklopedija Slovenije (Vol. 15, pp. 35-38). Mladinska knjiga.

Špehonja, N. (2010). Vocabolario nediško-italiano. http://bos.zrc-sazu.si/c/Dial/Nadisko_narecje /Spehonja_2010_vocabolario_nedisko_italiano.pdf

Špehonja, N. (2012). Nediška gramatika. Grammatica del nediško. Communità Montana del Torre, Natisone e Collio; Fondazione CRUP. http://bos.zrc-sazu.si/c/Dial/Spehonja /Spehonja\%202012\%20--\%20Nediska\%20gramatika.pdf

Spinozzi Monai, L. (2009). Il Glossario del dialetto del Torre di Jan Baudouin de Courtenay. Consorzio Universitario del Friuli; St. Petersburg's Branch of the Archive of the Russian Academy of Sciences; ZRC SAZU, Inštitut za slovenski jezik Frana Ramovša.

Steenwijk, H. (1992). The Slovene dialect of Resia: San Giorgio. Rodopi.

Utěšený, S. (1964). Z druhé výpravy za češtinou v rumunském Banátě. Českýlid, 1964(51), 27-32.

Zuljan Kumar, D. (2003). Nekaj besednorednih posebnosti v nadiškem in briškem narečju. Jezikoslovni zapiski, 9(2), 59-80. https://doi.org/10.3986/jz.v9i2.2589

Zuljan Kumar, D. (2014). Podredne stavčne strukture v nadiškem in briškem narečju. Annales: Ser. hist. sociol., 24(2), 331-342.

\section{BIBLIOGRAPHY}

\section{(TRANSLITERATION)}

Arkad'ev, P. M. (2016). Roli, ierarkhii i dvoŭnoe markirovanie ob"ektov. Voprosy iazykoznaniia, 2016(5), 7-48.

Baudouin de Courtenay, J. (1988). Materiali per la dialettologia e l'etnografia slava meridionale: Vol. 4. Testi popolari in prosa e in versi raccolti in Val Natisone nel 1873 / Materiali za južnoslovansko dialektologijo in etnografijo: Vol. 4. Ljudska besedila v prozi in verzih, zbrana v Nadiških dolinah leta 1873 (L. Spinozzi Monai, Ed.). Editoriale stampa triestina; Centro studi Nediža.

Benacchio, R. (2007). Slovansko-romanski jezikovni stik v moližanski hrvaščini: Vzporednost s slovenskimi narečji v Furlaniji. Jezikoslovni zapiski, 13(1-2), 33-41. https://doi.org /10.3986/jz.v13i1-2.2474 
Boduèn-de-Kurtenè, I. A. (1904). Materīaly dlia iuzhnoslavianskoù dīalektologīi i ètnografīi: Pt. 2. Obraztsy iazyka na govorakh Terskikh slavian sieverovostochnoı̆ Italīi. Tipografiia imperatorskoŭ akademii nauk.

Breu, W. (2019). Morphosyntactic changes in Slavic micro-languages: The case of Molise Slavic in total language contact. In A. Danylenko \& M. Nomachi (Eds.), Slavic on the language map of Europe: Historical and areal-typological dimensions (pp. 385-432). De Gruyter Mouton. https://doi.org/10.1515/9783110639223-013

Chelysheva, I. I. (2001). Dialekty Italii. In I. I. Chelysheva, B. P. Narumov, \& O. I. Romanova (Eds.), IAzyki mira: Romanskie iazyki (pp.90-146). Academia.

Chelysheva, I. I., \& Cherdantseva, T. Z. (2001). Ital'ianskiı̌ iazyk. In I. I. Chelysheva, B. P. Narumov, \& O. I. Romanova (Eds.), IAzyki mira: Romanskie iazyki (pp. 56-90). Academia.

Dapit, R. (2007). Položaj sodobnega slovenskega jezika na Videmskem. In. M. Košuta (Ed.), Živeti mejo (pp. 170-180). Slavistično društvo Slovenije.

Erat, J. (2008). Furlansko-slovenski slovar: I Dizionari furlan-sloven. http://sabotin.p-ng.si / jezik/furlanscina/

Frnochová, A. (2012). Jazyk české menšiny v obci Šumice v rumunském Banátě [Unpublished Master's thesis]. Univerzita Karlova.

Hočevar, M. (1990). Nadiško narečje (glasovje in besedje) v humorističnih sestavkih doma. Slavistična revija, 1990(3), 285-294.

Ivančič Kutin, B. (2016). Bivališča krivopet: Lokacije in mikrotoponimi. Studia Mythologica Slavica, 19, 169-185. https://doi.org/10.3986/sms.v19i0.6620

Logar, T. (1983). Slovenska narečja. Mladinska knjiga.

Lukht, L. I., \& Narumov, B. P. (2001). Rumynskiǔ iazyk. In I. I. Chelysheva, B. P. Narumov, \& O. I. Romanova (Eds.), IAzyki mira: Romanskie iazyki (pp. 574-636). Academia.

Mezgec, M. (2017). Slovenščina v beneški Sloveniji in vloga dvojezične šole v Špetru pri medgeneracijskem prenosu jezika: stališča staršev. Slovenščina 2.0, 5(2), 1-32. https://doi.org /10.4312/slo2.0.2017.2.1-32

Narumov, B. P., \& Sukhachev, N. L. (2001). Friul'skiĭ iazyk. In I. I. Chelysheva, B. P. Narumov, \& O. I. Romanova (Eds.), IAzyki mira: Romanskie iazyki (pp. 365-391). Academia.

Narumov, B. P. (2001). Ispanskiǐ iazyk. In I. I. Chelysheva, B. P. Narumov, \& O. I. Romanova (Eds.), Iazyki mira: Romanskie iazyki (pp. 411-462). Academia.

Runić, M. (2018). Slovensko-romanski jezički kontakt na primeru dve pojave iz rezijskog. Slavia Meridionalis, 18, Article 1657. https://doi.org/10.11649/sm.1657

Šekli, M. (2007). Fonološki opis govora vasi Jevšček pri Livku nadiškega narečja slovenščine. Jezikoslovni zapiski, 13(1-2), 409-427. https://doi.org/10.3986/jz.v13i1-2.2508

Šekli, M. (2010). Zaimkovno podvajanje predmeta in osebka v rezijanskem narečju slovenščine: (S stališča jezikovnega stika s furlanščino). In Makedonsko-slovenečki jazični, kniževni i kulturni vrski/Makedonsko-slovenske jezikoslovne, književne in kulturne zveze (pp. 133155). Filološki fakultet "Blaže Koneski”, Univerzitet "Sv. Kiril i Metodij”.

Simić, Z. (2013). Prilog proučavanju međujezičke interferencije (na primeru govora Banatske Crne Gore). Južnoslovenski filolog, 2013(69), 429-441. https://doi.org/10.2298/JFI1369429S 
Skubic, M. (1986). Interferenze linguistiche slavo-romanze: La lingua di Novi Matajur. Linguistica, 26(1), 59-68. https://doi.org/10.4312/linguistica.26.1.59-68

Skubic, M. (1991). Interferenze sintattiche di origine romanza nelle parlate slovene occidentali: la strutturazione del sintagma aggettivale, della frase, del periodo. Linguistica, 31(1), 361-365. https://doi.org/10.4312/linguistica.31.1.361-365

Skubic, M. (1997a). Calchi di provenenza romanza nello sloveno occidentale. Linguistica, 37(1), 99-105.

Skubic, M. (1997b). Romanske jezikovne prvine na zahodi slovenski jezikovni meji. Znanstveni inštitut filozofske fakultete.

Smole, V. (2001). Zahodna slovenska narečja. In M. Javornik (Ed.), Enciklopedija Slovenije (Vol. 15, pp. 35-38). Mladinska knjiga.

Špehonja, N. (2010). Vocabolario nediško-italiano. http://bos.zrc-sazu.si/c/Dial/Nadisko_narecje /Spehonja_2010_vocabolario_nedisko_italiano.pdf

Špehonja, N. (2012). Nediška gramatika. Grammatica del nediško. Communità Montana del Torre, Natisone e Collio; Fondazione CRUP. http://bos.zrc-sazu.si/c/Dial/Spehonja /Spehonja\%202012\%20--\%20Nediska\%20gramatika.pdf

Spinozzi Monai, L. (2009). Il Glossario del dialetto del Torre di Jan Baudouin de Courtenay. Consorzio Universitario del Friuli; St. Petersburg's Branch of the Archive of the Russian Academy of Sciences; ZRC SAZU, Inštitut za slovenski jezik Frana Ramovša.

Steenwijk, H. (1992). The Slovene dialect of Resia: San Giorgio. Rodopi.

Utěšený, S. (1964). Z druhé výpravy za češtinou v rumunském Banátě. Českýlid, 1964(51), 27-32.

Zuljan Kumar, D. (2003). Nekaj besednorednih posebnosti v nadiškem in briškem narečju. Jezikoslovni zapiski, 9(2), 59-80. https://doi.org/10.3986/jz.v9i2.2589

Zuljan Kumar, D. (2014). Podredne stavčne strukture v nadiškem in briškem narečju. Annales: Ser. hist. sociol., 24(2), 331-342.

\section{Rezultaty kontaktów językowych w słoweńskim dialekcie Doliny Natisone, na wybranych przykładach}

W artykule omówiono niektóre zjawiska językowe jako rezultat kontaktów językowych z zakresu fonetyki, morfologii i składni, w słoweńskim dialekcie doliny Natisone we Włoszech, należącym do grupy dialektów przybrzeżnych. Celem artykułu jest ustalenie genezy tych zjawisk oraz opis sposobu funkcjonowania i obszarów występowania. Dane do analizy (wypowiedzi informatorów) zostały zebrane podczas badań terenowych w tym regionie. Ujawniają one następujące zjawiska: udźwięcznienie bezdźwięcznych spółgłosek zębowo-dziąsłowych przed sonornymi; zapożyczanie przyimków i spójników; postpozycja przymiotników w grupach rzeczownikowych; podwojenie zaimków i rzeczowników; wyrażanie dat przez określone konstrukcje czasowe. Okazuje się, że analizowane konstrukcje i formy charakteryzują się dużym stopniem zmienności, funkcjonują równolegle ze swoimi słoweńskimi odpowiedni- 
kami. W niektórych przypadkach mamy do czynienia $\mathrm{z}$ formami mieszanymi (mieszanymi konstrukcjami przyimkowymi, konstrukcjami czasowymi do wyrażania dat). Podwojenie zaimków i rzeczowników występuje na obszarze nierównomiernie, podobne zjawisko występuje w językach ligi bałkańskiej.

Słowa kluczowe: język słoweński, język włoski, zapożyczenia, kontakt językowy, dialekt, badania terenowe, Natisone Valley

\section{Some Contact-related Phenomena in the Slovenian Dialect of the Natisone Valley}

The paper discusses some contact-related phenomena in the phonetics, morphology and syntax of the Slovene dialect that is spoken in the Natisone Valley in Italy, a dialect belonging to the Littoral dialect group. The purpose of the study is to establish the origin of these phenomena and clarify the features of their functioning and areal distribution. The data for the analysis (oral speech of informants) was collected during field research in this region. The following phenomena are revealed: voicing of the voiceless dental alveolar $s$ before sonorants; borrowing of prepositions and conjunctions; postposition of adjectives in noun groups; doubling of pronouns and nouns; temporal constructions are used to express dates. It is revealed that the analyzed constructions and items have a high degree of variability: they function along with their Slovenian counterparts. In some cases, we are dealing with contaminated forms (contaminated prepositions, temporal construction for expressing dates). The doubling of pronouns and nouns forms a broken area, and a similar phenomenon is found in the languages of the Balkan Sprachbund.

Keywords: Slovenian language, Italian language, borrowing, language contact, dialect, field research, Natisone Valley

\section{Notka o autorze}

Gleb Pilipenko (pilipenko.gleb.petrovich@gmail.com) - doktor, pracuje w Instytucie Slawistyki Rosyjskiej Akademii Nauk w Moskwie, gdzie w 2011 roku obronił doktorat z filologii. Jego zainteresowania naukowe obejmują językoznawstwo kontaktowe, dialektologię słowiańską i etnolingwistykę. 
Zajmuje się badaniem języka i tożsamości grup mniejszości słowiańskiej oraz sytuacją językową Węgrów żyjących wśród ludności słowiańskiej. Prowadził również badania terenowe w Europie i Ameryce Południowej. Autor wielu publikacji, m.in monografii: Языковая и этнокультурная ситуация воеводинских венгров: взгляд «изнутри» и «извне» [Sytuасја językowa i etniczno-kulturowa Węrów w Wojwodinie: Spojrzenie „od wewnątrz” i „z zewnątrz”, Moskwa-Petersburg, 2017] i artykułów: The Ukrainian language in Argentina and Paraguay as an identity marker [Język ukrainski $w$ Argentynie i Paragwaju jako wyznacznik tożsamości, 2018], Hungarian-Slavic bilingualism in Transcarpathia, Vojvodina and Prekmurje [Dwujęzyczność węiersko-słowiańska nа Zakarpaciu, Wojwodinie i Prekmurju, 2016], Метаязыковые высказывания старообрядиев Латгалии [Metajęzykowe wypowiedzi staroobrzędowców w Łatgalii, 2017], Переключение кода в русском языке старообрядиев Латzалиu [Przełaczanie kodów w języku rosyjskim przez staroobrzędowców w Łatgalii, 2017], Дискурсивные практики в речи украинцев Боснии и Герuеговины [Praktyki dyskursywne w mowie Ukraińców mieszkających w Bośni i Hercegowinie, 2020].

Gleb Pilipenko (pilipenko.gleb.petrovich@gmail.com) - PhD, works at the Institute of Slavic Studies of the Russian Academy of Sciences in Moscow, where he received his $\mathrm{PhD}$ in Philology in 2011. His scholarly interests include contact linguistics, Slavic dialectology and ethnolinguistics. He investigates the language and identity of Slavic minority groups and the language situation of Hungarians living among Slavic peoples. Gleb Pilipenko has also conducted field studies in Europe and South America. Author of many publications, including Языковая и этнокультурная ситуация воеводинских венгров: взгляд «изнутри» и «извне» [The language and ethno-cultural situation of Hungarians in Vojvodina: A view "from inside" and "from outside", Moscow-Saint Petersburg, 2017] and articles The Ukrainian language in Argentina and Paraguay as an identity marker (2018), Hungarian-Slavic bilingualism in Transcarpathia, Vojvodina and Prekmurje (2016), Метаязыковые высказывания старообрядиев Латгалии [The metalinguistic utterances of Old Believers in Latgale, 2017], Переключение кода в русском языке старообрядиев Латгалии [Code-switching in Russian by Old Believers in Latgale, 2017], Дискурсивные практики в речи украинцев Боснии и Гериего- 
Глеб Пилипенко Некоторые контактнообусловленные явления в словенском диалекте...

вины [Discursive practices in the speech of the Ukrainians living in Bosnia and Herzegovina, 2020].

Publication History: Received: 2021-2020-09-15; Accepted: 2021-04-24; Published: 2021-12-23

Page 20 of 20 